\title{
MODEL PRAKIRAAN DEBIT AIR DALAM RANGKA OPTIMALISASI PENGELOLAAN WADUK SAGULING- KASKADE CITARUM
}

\author{
FLOWRATE ESTIMATION MODEL FOR MANAGEMENT \\ OPTIMALIZATION OF SAGULING-CASCADE CITARUM \\ RESERVOIR
}

\author{
Mariana Marselina, Arwin Sabar \\ Fakultas Teknik Sipil dan Lingkungan, Institut Teknologi Bandung, Jl. Ganesha No. \\ 10 Bandung, 40132, \\ E-mail: mariana.marselina@yahoo.com arwin@yahoo.com
}

\begin{abstract}
Abstrak
Peningkatan laju pertumbuhan penduduk dan industri mendorong peningkatan kebutuhan akan energi listrik. Salah satu penyedia kebutuhan energi listrik di wilayah Jawa, Madura, Bali (Jamali) adalah Waduk Saguling. Rata-rata produksi listrik Waduk Saguling dari tahun 1986-2014 adalah 2.334.318,138 MWh/tahun. Asupan air bagi Waduk Saguling adalah Daerah Aliran Sungai (DAS) Citarum Hulu dengan luas $2.340,88 \mathrm{~km}^{2}$. Waduk Saguling juga merupakan salah satu waduk yang membentuk waduk series di kaskade Citarum yang terdiri dari Waduk Saguling, Cirata, dan Jatiluhur. Pemanfaatan Waduk Jatiluhur sebagai waduk multiguna untuk sumber air baku, irigasi, dan PLTA pun masih belum optimal, hal ini ditandai dengan terjadinya kekurangan air di hilir pada musim kering dan air melimpas pada musim hujan. Tujuan optimasi Waduk Saguling pada penelitian ini adalah memaksimalkan penggunaan air sehingga dapat memenuhi kebutuhan bagi pembangkit listrik dan memenuhi kebutuhan air di downstream dengan mempertimbangkan prakiraan debit masa depan. Pendekatan prakiraan debit yang dilakukan dalam pengelolaan waduk adalah dengan metode korelasi spasial (hujan dan debit) atau metode kontinu serta dengan metode diskrit Markov yang menggunakan prinsip model stokastik Markov 3 kelas. Data debit inflow Waduk Saguling yang digunakan adalah data debit dari tahun 1986-2013. Pada metode korelasi spasial diperoleh kombinasi tipe $P P P Q_{t-1}$ memiliki nilai korelasi sebesar 0,86 sedangkan untuk metode diskrit Markov diperoleh nilai korelasi sebesar 0,804.
\end{abstract}

Kata Kunci: metode diskrit Markov, metode korelasi spasia, prakiraan debit

\begin{abstract}
The increasing growth of population and industrial sector have lead to an enhanced demand for raw water and electrical energy. One of the electricity providers in the area of Java,Madura, Bali (Jamali) is Saguling Reservoir. Saguling Reservoir is also one of the three reservoirs that stem the flow of Citarum River beside Jatiluhur and Cirata Reservoir. The average electricity production of Saguling Reservoir was 2,334,318.138 MWh/year in the period of 1986-2014. The water intake of Saguling Reservoir is the upstream Citarum Watershed with an area of $2340.88 \mathrm{~km}^{2}$ which also serves as the irrigation, inland fisheries, recreation, and other activities in the downstream. Utilization of Jatiluhur as downstream reservoir of Saguling where Jatiluhur is used for raw water sources, irrigation, and hydropower was still not optimal. It was characterized by a shortage of water downstream during the dry season and overflow during the rainy season. This research aimed to optimize Saguling reservoir by maximizing the use of water to meet the needs for power generation and water needs in downstream; taking into account forecasts of future discharge. Discharge forecasting approach in the reservoirs management is the spatial correlation method (rainfall and discharge) or a method of continuous and discrete Markov that use the principle of 3 class stochastic Markov model. Saguling inflow discharge data used is the data flow from the year 1986 to 2013. In the spatial correlation method, combined
\end{abstract}


$P P P Q_{t-1}$ obtained had a correlation value of 0.86 while for discrete Markov method obtained the correlation value of 0.804 .

Keywords: discrete Markov method, forecast discharge, spatial correlation method

\section{PENDAHULUAN}

Alokasi air adalah kekhawatiran di negara berkembang di mana sumber daya air yang terbatas yang terbatas dan permintaan yang lebih besar dengan lebih banyak pihak (Read et.al, 2014). Waduk menyediakan pasokan air, perlindungan banjir, dan manfaat pembangkit listrik tenaga air (Null et.al, 2014). Keberadaan waduk dapat membuat penggunaan sumber daya air untuk masyarakat manusia lebih efisien sehinggga pengoperasian waduk secara optimal, dianggap penting. Sebuah model optimal waduk multi guna diusulkan untuk mengurangi konflik antara penggunaan air dan kerusakan lingkungan (Xu et.al , 2014).

Sumber daya air adalah sumber daya alam yang dapat diperbaharui melalui siklus hidrologi dan merupakan fungsi ruang dan waktu (Arwin, 2009). Sumber air dapat diperbarui melalui siklus hidrologi, dipengaruhi oleh iklim, konversi lahan membentuk komponen rezim hidrologi (hujan dan debit) yang berkarakter acak dan stokastik, sedangkan pada kemiringan relatif landai pembuangan air dari daratan laut merupakan fenomena deterministik.

Pengetahuan tentang beberapa periode hujan diperlukan untuk desain struktur hidrolik seperti perlindungan banjir, infrastruktur air minum dan sistem saluran drainase (Benabdesselam, 2013). Hubungan antara hujan dan debit merupakan dasar peramalan yang tepat untuk pengoperasian proyek hidrolik dan untuk memperpanjang data debit. Untuk dapat meramalkan debit dimasa depan secara akurat atau mendekati kenyataan dilapangan, dibutuhkan ketepatan pemilihan metode perhitungan serta data input yang memadai. Komponen hidrologi yang mendasari peramalan debit yang paling banyak digunakan adalah komponen hujan dan debit karena dari hasil penelitian kedua komponen tersebut adalah komponen yang paling berpengaruh terhadap ketersediaan debit dibanding komponen hidrologi lainnya. Oleh karena itu dalam penelitian ini kemudian kedua komponen tersebut (hujan dan debit) kemudian dimodifikasi menjadi beberapa alternatif untuk kemudian dilihat kombinasi yang menghasilkan nilai korelasi yang tertinggi.

\section{METODA}

Lokasi penelitian yang berupa Waduk Saguling yang terletak di wilayah Kabupaten Sragen yang berada di Provinsi Jawa Barat, Indonesia. Data curah hujan dan debit pada penelitian ini diambil dari pos pos pencatatan hujan dan debit yang ada di DAS Waduk Saguling. Data yang didapatkan tidak selalu lengkap sehingga diperlukan perhitungan regresi linier untuk memperkirakan data kosong (Abatzoglou, 2009).

Teknik pengisian data kosong pada penelitian ini mengunakan korelasi spartial empat variabel dimana tiga pos hujan menjadi penjelas dan satu pos hujan lagi menjadi yang dijelaskan. Korelasi terbesar antar stasiun dipilih sebagai stasiun pengisi dan dibuatkan persamaan regrasi sebagai persamaan pengisian data hujan. Untuk melengkapi data debit juga digunakan korelasi spartial empat variabel dimana dua pos hujan dan satu pos debit sebagai penjelas.

Model kontinu hujan-debit didasarkan pada korelasi antara stasiun hujan dengan stasiun debit. Dari penelitian diketahui bahwa model korelasi yang melibatkan empat variabel hidrologi, lebih efektif dalam menentukan hubungan antar hujan-debit. Hubungan dengan lebih dari empat variabel tidak memberikan hasil yang berarti (kenaikan koefisien determinasi relatif kecil).

Hubungan hujan dan debit sungai merupakan dasar peramalan yang tepat untuk pengoperasian projek-projek pengembangan sumber daya air dan perluasan data debit aliran sungai. Data pengukuran debit sungai sering kali tidak lengkap. Salah satu cara yang digunakan untuk 
melengkapinya adalah dengan cara regresi linier berganda menggunakan korelasi sparsial $\mathrm{F}(\mathrm{x}, \mathrm{y}, \mathrm{z}, \mathrm{t})$ komponen utama hidrologi ( $\mathrm{P}$ dan $\mathrm{Q})$, (Arwin, 2002). Model kontinu prakiraan debit menggunakan metode korelasi regresi linier ganda (Arwin, 2002) dibangun berdasarkan korelasi antara dua variabel acak, yaitu data stasiun pengamat hujan $(\mathrm{P})$ dan data stasiun pengamat debit (Q). Model dengan nilai koefisien determinasi (R2) terbesar dipilih sebagai model yang paling baik untuk membangun data debit. Lokasi penelitian dan model kontinu prakiraan debit dapat dilihat pada Gambar 1 dan Gambar 2.
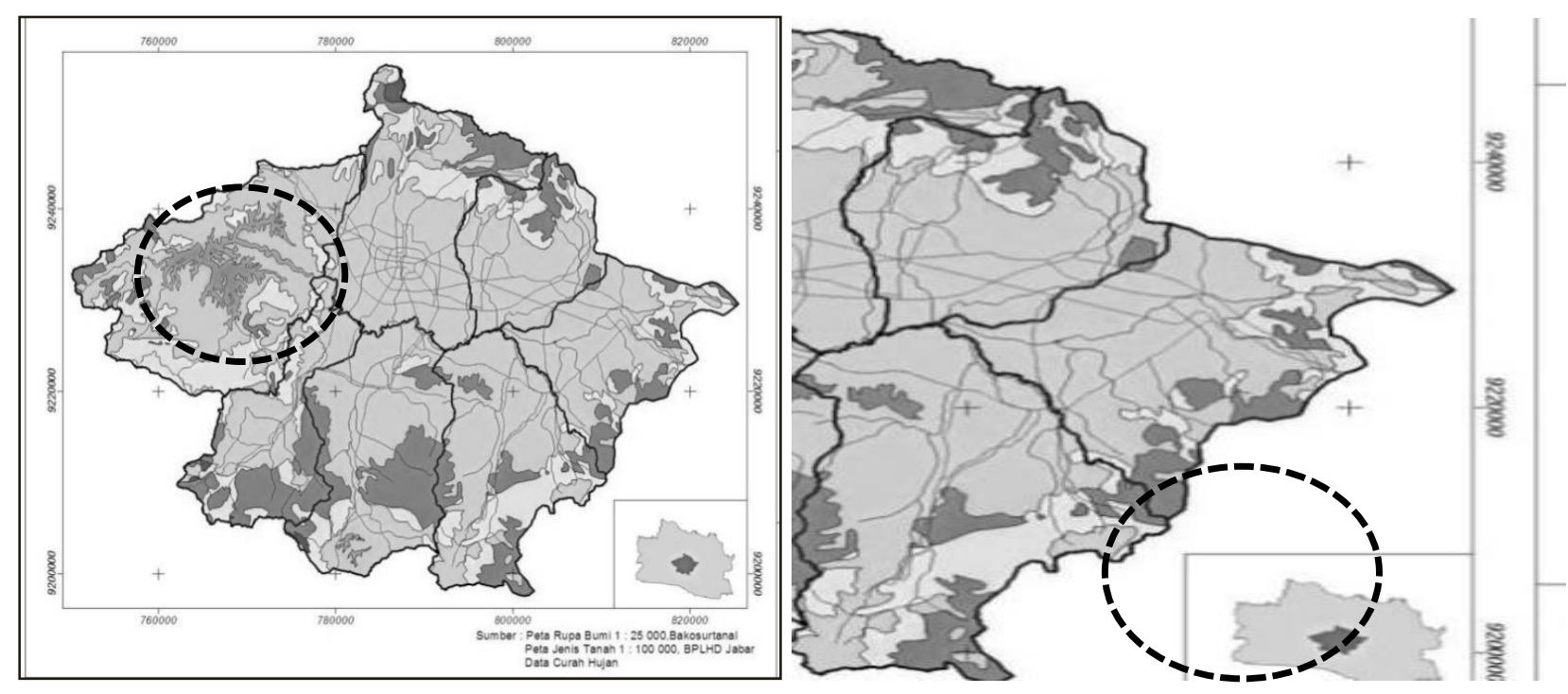

Gambar 1. Lokasi penelitian

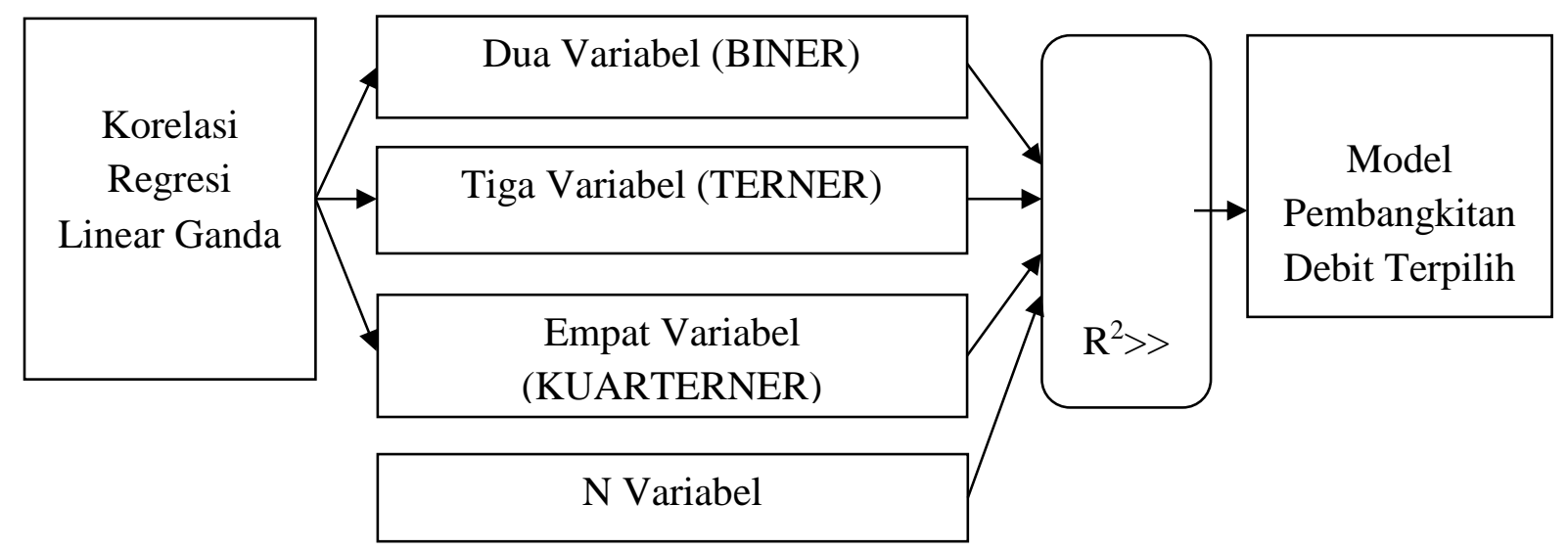

Gambar 2. Model Kontinu Prakiraan Debit Masa Depan (Arwin, 2002)

Model Terner (Korelasi Tiga Variabel Acak)

Model kontinu terner terdiri dari 3 (tiga) variabel siklus hidrologi tipe ketautan model terner terdiri dari dua stasiun penjelas $\left(\mathrm{X}_{2}\right.$ dan $\left.\mathrm{X}_{3}\right)$ untuk menjelaskan satu stasiun yang dijelaskan $\left(\mathrm{X}_{1}\right)$. Skema korelasi antara ketiga stasiun tersebut dijelaskan pada Gambar 2.
Persamaan regresi linier dari model terner dinyatakan sebagai berikut (Arwin, 2002):

$$
x_{1}=r_{2} x_{2}+r_{3} x_{3}+\varepsilon
$$

Dengan:

$$
x_{1}=\frac{X_{i}-\bar{X}}{\sigma}, \mathrm{i}=1,2, \operatorname{dan} 3
$$


Koefisien korelasi parsiil diekspresikan sebagai berikut (Arwin, 2002):

$$
\begin{aligned}
& r_{2}=\frac{\rho_{12}-\rho_{13} \rho_{23}}{1-\rho_{23}^{2}} \\
& r_{3}=\frac{\rho_{13}-\rho_{12} \rho_{23}}{1-\rho_{23}^{2}}
\end{aligned}
$$

Persamaan koefisien determinasi model terner dituliskan sebagai berikut (Arwin, 2002):

$$
\begin{aligned}
& R^{2}=\frac{\left(\rho_{12}^{2}+\rho_{13}^{2}-2 \rho_{12} \rho_{13} \rho_{23}\right)}{1-\rho_{23}^{2}} \\
& \varepsilon 2=1-R^{2}
\end{aligned}
$$

Model terner dapat digunakan pada DAS untuk pengelolaan waduk dengan ketidakpastian masa yang akan datang. Model ini terdiri dari tiga tipe yaitu model terner tipe $\mathrm{PP}(\mathrm{Q} 1)$, tipe $\mathrm{PQ}(\mathrm{Q} 1)$, dan tipe QQ(Q1).

\section{Model Kuaterner (Korelasi Empat Variabel Acak)}

Model kuaterner terdiri dari empat stasiun hidrologi yaitu tiga stasiun penjelas $\left(\mathrm{X}_{2}, \mathrm{X}_{3}\right.$, dan $\mathrm{X}_{4}$ ) dan satu stasiun yang akan dijelaskan $\left(\mathrm{X}_{1}\right)$. Skema korelasi model ini dapat dituliskan sebagai berikut:

Persamaan regresi linier model kuaterner dinyatakan sebagai berikut (Arwin, 2002):

$$
x_{1}=r_{2} x_{2}+r_{3} x_{3}+r_{4} x_{4}+\varepsilon
$$

Dengan:

$$
\Sigma x_{1} x_{j}=\mathrm{r}_{2} \Sigma x_{2} x_{j}+r_{3} \Sigma x_{3} x_{j}+r_{4} \Sigma x_{4} x_{j}
$$

Asumsi $E(\varepsilon x j)=0$ untuk $j=2,3$, dan 4 .

Nilai ri dapat dihitung dengan menggunakan persamaan Yule Walker sebagai berikut:

$$
\left|\begin{array}{ccc}
1 & \rho_{12} & \rho_{24} \\
\rho_{23} & 1 & \rho_{34} \\
\rho_{24} & \rho_{34} & 1
\end{array}\right|\left|\begin{array}{c}
r_{2} \\
r_{3} \\
r_{4}
\end{array}\right|=\left|\begin{array}{c}
\rho_{12} \\
\rho_{13} \\
\rho_{14}
\end{array}\right|
$$

Koefisien determinasi R2 dan kesalahan relatif $\varepsilon$ dihitung dengan persamaan sebagai berikut:

$$
\begin{gathered}
\varepsilon=1+r_{22}+r_{32}+r_{42}-2\left(r_{2} \rho_{12}+r_{3} \rho_{13}+r_{4} \rho_{14}\right)+ \\
2\left(r_{2} r_{3} \rho_{23}+r_{2} r_{4} \rho_{24}+r_{3} r_{4} \rho_{34}\right) \\
R^{2}=1-\varepsilon 2
\end{gathered}
$$

Model kuaterner dapat digunakan pada DAS untuk pengelolaan waduk air dengan ketidakpastian masa yang akan datang. Model ini terdiri dari empat tipe yaitu model kuartener tipe PPP(Q1), tipe PPQ(Q1), tipe PQQ(Q1).

\section{Model Diskrit Markov 3 Kelas Orde 1}

Model diskrit Markov terdiri dari 2 (dua) tarikan dimana tarikan pertama adalah penentuan kondisi dan tarikan kedua adalah penentuan besaran. Probabilitas kejadian pada suatu waktu tertentu bergantung/ditentukan hanya dari kejadian waktu sebelumnya.

Karena data debit bersifat stokastik, maka pendekatan dengan model Markov dibuat melalui pembuatan matrik transisi untuk menjelaskan mengenai nilai probabilitas (ketidakpastian) kejadian besaran debit tertentu dimana jumlah probabilitas seluruh kejadian sama dengan 1 .

Kedua matrik $\mathrm{P}$ diatas disebut matrik transisi homogen atau matriks stokhastik karena semua transisi probabilitas $\mathrm{Pij}$ adalah tetap dan independen terhadap waktu. Probabilitas Pij harus memenuhi kondisi:

$\sum_{j} \mathrm{P}_{\mathrm{ij}}=1$ untuk seluruh nilai $i$;

$\mathrm{P}_{\mathrm{ij}} \geq 0$ untuk seluruh nilai $i$ dan $j$ 
Tabel 1. Matrik transisi orde satu (Arwin, 2002) Kondisi Debit Kondisi Debit Waktu $t_{n}$

\begin{tabular}{cccccc} 
Waktu $\mathrm{t}_{\mathrm{n}-1}$ & 0 & 1 & 2 & $\ldots$ & $\mathrm{N}$ \\
\hline 0 & $\mathrm{P}_{00}$ & $\mathrm{P}_{01}$ & $\mathrm{P}_{02}$ & $\ldots$ & $\mathrm{P}_{0 \mathrm{~N}}$ \\
1 & $\mathrm{P}_{10}$ & $\mathrm{P}_{11}$ & $\mathrm{P}_{12}$ & $\ldots$ & $\mathrm{P}_{1 \mathrm{~N}}$ \\
2 & $\mathrm{P}_{20}$ & $\mathrm{P}_{21}$ & $\mathrm{P}_{22}$ & $\ldots$ & $\mathrm{P}_{2 \mathrm{~N}}$ \\
$\ldots$ & $\ldots$ & $\ldots$ & $\ldots$ & $\ldots$ & $\ldots$ \\
$\mathrm{N}$ & $\mathrm{P}_{\mathrm{N} 0}$ & $\mathrm{P}_{\mathrm{N} 1}$ & $\mathrm{P}_{\mathrm{N} 2}$ & $\ldots$ & $\mathrm{P}_{\mathrm{NN}}$ \\
\hline
\end{tabular}

\section{HASIL DAN PEMBAHASAN}

Debit Prakiraan Metode Korelasi Spasial Hujan dan Debit

Dalam perhitungan debit prakiraan dengan menggunakan metode korelasi spasial hujan dan debit digunakan alat bantu SPPS dengan menggunakan komponen PPPQ $_{\mathrm{t}-1}$ dan menghasilkan nilai korelasi sebesar 0,86 terhadap debit aktual.

Tabel 2. Persamaan debit prakiraan metode korelasi spasial

\begin{tabular}{ll}
\hline Bulan & \multicolumn{1}{c}{ Persamaan } \\
\hline Januari & Qjan $=(0,0621) \mathrm{P} 2+(0,3148) \mathrm{P} 10+(0,2141)$ Qdes $+16,449$ \\
\hline Februari & Qfeb $=(0,3020) \mathrm{P} 4+(0,2080) \mathrm{P} 6+(0,4451)$ Qjan $-3,014$ \\
\hline Maret & Qmar $=(0,1566) \mathrm{P} 6+(0,2885) \mathrm{P} 10+(0,3172)$ Qfeb $+0,8306$ \\
\hline April & Qapr $=(0,0987) \mathrm{P} 2+(0,0978) \mathrm{P} 7+(0,3328)$ Qmar $+64,625$ \\
\hline Mei & Qmei $=(0) \mathrm{P} 2+(0) \mathrm{P} 3+(1)$ Qapr +0 \\
\hline Juni & Qjun $=(0,2013) \mathrm{P} 3+(0,1742) \mathrm{P} 4+(0,2585)$ Qmei $+9,4927$ \\
\hline Juli & Qjul $=(0,1746) \mathrm{P} 2+(0,0842) \mathrm{P} 10+(0,0688)$ Qjuni $+23,7672$ \\
\hline Agustus & Qagt $=(0,1030) \mathrm{P} 2+(0,1659) \mathrm{P} 8+(0,0764)$ Qjuli $+6,494$ \\
\hline September & Qsept $=(0,0555) \mathrm{P} 1+(0,2558) \mathrm{P} 2+(0,2411)$ Qagustus $+8,9508$ \\
\hline Oktober & Qokt $=(0,2108) \mathrm{P} 4+(0,0828) \mathrm{P} 7+(0,4556)$ Qseptember $+3,4011$ \\
\hline Nopember & Qnov $=(0,2108) \mathrm{P} 10+(0,0828) \mathrm{P} 4+(0,4556)$ Qoktober $-7,5567$ \\
\hline Desember & Qdes $=(0,3598) \mathrm{P} 10-(0,004) \mathrm{P} 2+(0,2700)$ Qnovember $+12,6486$ \\
\hline
\end{tabular}

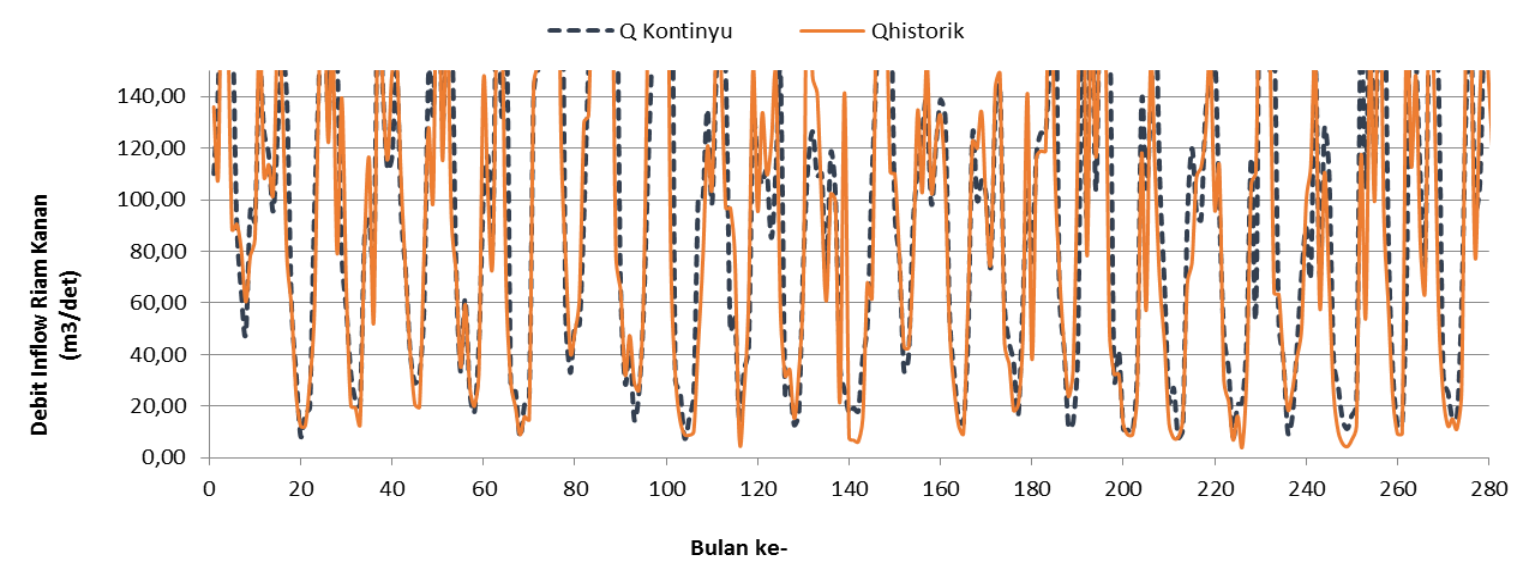

Gambar 3. Perbandingan debit historik dan debit bangkitan model kontinu 


\section{Debit Prakiraan Metode Diskrit Markov 3 Kelas Orde 1}

Model prakiraan debit dengan model diskrit Markov yaitu peramalan debit masa depan dengan menggolongkan debit ke dalam 3 kelas debit, yaitu kering, normal, dan basah yang diurutkan mulai dari data debit yang terkecil hingga yang terbesar. Debit yang akan diklasifikasikan berasal dari debit input bulanan historis. Batas kelas debit untuk masing-masing kelas terlihat dalam Tabel 3.

Tabel 3. Batas kelas debit bulanan Waduk Saguling (1986-2013)

\begin{tabular}{cccc}
\hline Bulan & $\begin{array}{c}\text { Kelas } \\
\text { kering (0) }\end{array}$ & $\begin{array}{c}\text { Kelas } \\
\text { normal (1) }\end{array}$ & $\begin{array}{c}\text { Kelas } \\
\text { basah (2) }\end{array}$ \\
\hline Jan & 76,62 & 123,18 & 183,24 \\
Feb & 90,14 & 130,83 & 202,24 \\
Mar & 90,34 & 150,17 & 218,46 \\
Apr & 109,92 & 154,58 & 217,09 \\
May & 62,12 & 98,50 & 143,12 \\
Jun & 26,39 & 57,80 & 95,08 \\
Jul & 16,00 & 31,79 & 77,27 \\
Aug & 7,59 & 14,82 & 47,27 \\
Sep & 9,25 & 18,35 & 55,53 \\
Oct & 12,05 & 40,12 & 102,12 \\
\hline
\end{tabular}

\begin{tabular}{llll}
\hline Nov & 35,96 & 100,58 & 173,30 \\
Dec & 78,11 & 122,17 & 172,01 \\
\hline
\end{tabular}

Setelah mengetahui interval debit untuk masingmasing kelas dan nilai rata-rata debit masingmasing kelas (basah-normal-kering), data debit historik kemudian ditransformasikan ke dalam kelas 0-1-2. Lalu dengan menggunakan matriks transisi bulanan seperti contoh Tabel 4, dilakukan prakiraan kondisi di bulan berikutnya (basah-normal-kering) yang hasilnya dapat dilihat pada Tabel 5. Setelah itu, akan didapatkan nilai prakiraan debit yang besarannya sesuai dengan nilai rata-rata debit masing-masing kelas (basah-normal-kering) yang telah didapatkan sebelumnya yang disajikan dalam

Tabel 6.

Tabel 4. Matriks transisi bulanan Markov 3

kelas orde 1

\begin{tabular}{cccccc}
\hline \multirow{2}{*}{$\begin{array}{c}\text { Kondisi } \\
\text { Bulan }\end{array}$} & \multicolumn{6}{c}{ Kondisi Debit } & & \\
& 0 & 1 & 2 & & \\
\hline 0 & 0,57 & 0,14 & 0,29 & 1 & P0N \\
1 & 0,29 & 0,29 & 0,43 & 1 & P1N \\
2 & 0,14 & 0,57 & 0,29 & 1 & P2N \\
& & & & 3 & PNN \\
& P0N & P1N & P2N & PNN & \\
\hline
\end{tabular}

Tabel 5. Klasifikasi debit input bulanan Waduk Saguling dengan Model Markov (1986-2013)

\begin{tabular}{ccccccccccccc}
\hline Tahun & Jan & Feb & Mar & Apr & May & Jun & Jul & Aug & Sep & Oct & Nov & Des \\
\hline 1986 & 1 & 1 & 2 & 2 & 1 & 2 & 2 & 2 & 2 & 2 & 2 & 1 \\
1987 & 1 & 0 & 1 & 0 & 0 & 1 & 1 & 1 & 0 & 1 & 0 & 1 \\
1988 & 2 & 1 & 1 & 0 & 2 & 1 & 0 & 1 & 1 & 2 & 1 & 0 \\
1989 & 2 & 1 & 0 & 1 & 2 & 2 & 2 & 2 & 1 & 0 & 1 & 1 \\
1990 & 0 & 2 & 0 & 2 & 1 & 1 & 1 & 2 & 2 & 0 & 0 & 1 \\
1991 & 0 & 0 & 1 & 1 & 0 & 0 & 0 & 0 & 1 & 0 & 2 & 2 \\
1992 & 2 & 2 & 2 & 2 & 2 & 2 & 2 & 2 & 2 & 2 & 1 & 2 \\
1993 & 2 & 2 & 2 & 2 & 1 & 1 & 1 & 2 & 2 & 1 & 1 & 2 \\
1994 & 2 & 2 & 2 & 2 & 0 & 0 & 0 & 0 & 0 & 0 & 0 & 0 \\
1995 & 1 & 0 & 1 & 1 & 1 & 2 & 2 & 0 & 1 & 1 & 2 & 0 \\
1996 & 1 & 0 & 1 & 1 & 0 & 0 & 1 & 1 & 2 & 2 & 2 & 2 \\
1997 & 1 & 0 & 0 & 0 & 1 & 0 & 2 & 0 & 0 & 0 & 0 & 0 \\
1998 & 0 & 2 & 2 & 2 & 1 & 2 & 2 & 2 & 2 & 2 & 2 & 0 \\
1999 & 2 & 0 & 1 & 0 & 1 & 1 & 1 & 1 & 0 & 1 & 1 & 1 \\
2000 & 1 & 0 & 0 & 1 & 2 & 1 & 1 & 1 & 1 & 1 & 2 & 0 \\
2001 & 1 & 1 & 1 & 2 & 2 & 2 & 2 & 2 & 2 & 2 & 2 & 0 \\
\hline
\end{tabular}




\begin{tabular}{lllllllllllll}
\hline 2002 & 2 & 1 & 2 & 1 & 0 & 0 & 1 & 1 & 0 & 0 & 0 & 1 \\
2003 & 0 & 1 & 0 & 0 & 0 & 0 & 0 & 0 & 1 & 2 & 1 & 1 \\
2004 & 1 & 1 & 1 & 0 & 1 & 0 & 0 & 0 & 1 & 0 & 0 & 1 \\
2005 & 1 & 2 & 2 & 1 & 0 & 1 & 1 & 1 & 1 & 1 & 0 & 0 \\
2006 & 1 & 1 & 0 & 0 & 0 & 0 & 0 & 0 & 0 & 0 & 0 & 1 \\
2007 & 0 & 2 & 0 & 2 & 1 & 1 & 0 & 0 & 0 & 2 & 1 & 2 \\
2008 & 0 & 0 & 2 & 0 & 0 & 0 & 0 & 1 & 0 & 1 & 2 & 2 \\
2009 & 0 & 1 & 1 & 1 & 2 & 2 & 1 & 1 & 1 & 1 & 1 & 0 \\
2010 & 2 & 2 & 2 & 1 & 2 & 2 & 2 & 2 & 2 & 2 & 2 & 2 \\
2011 & 0 & 0 & 0 & 0 & 2 & 1 & 1 & 1 & 0 & 0 & 1 & 1 \\
2012 & 0 & 1 & 0 & 1 & 1 & 1 & 0 & 0 & 1 & 1 & 1 & 2 \\
2013 & 2 & 2 & 1 & 2 & 2 & 2 & 2 & 2 & 2 & 1 & 0 & 2 \\
\hline
\end{tabular}

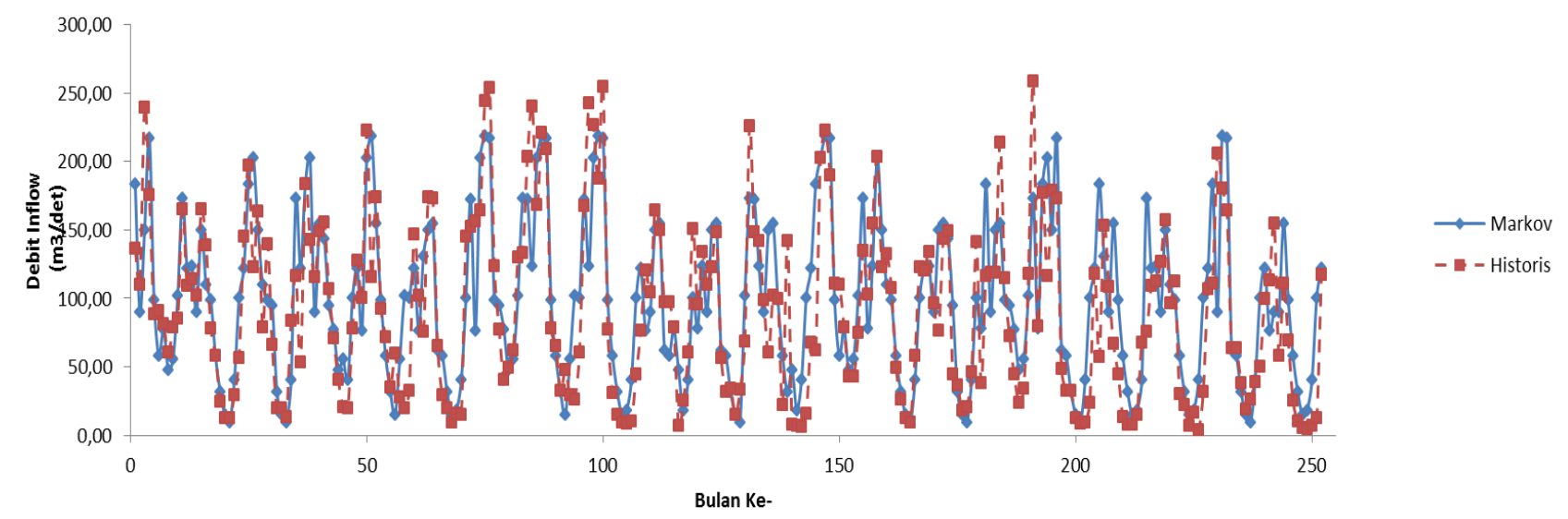

Gambar 4. Kalibrasi debit prakiraan model Chain Markov dengan debit input historis Waduk Saguling (1986-2013)

Tabel 6. Data debit bulanan (m3/s) Waduk Saguling hasil prakiraan model Chain Markov orde 3 (1986-2013)

\begin{tabular}{rrrrlrlllllll}
\hline Tahun & \multicolumn{1}{l}{ Jan } & \multicolumn{1}{c}{ Feb } & \multicolumn{1}{l}{ Mar } & Apr & \multicolumn{1}{l}{ May } & Jun & Jul & Aug & \multicolumn{1}{l}{ Sep } & \multicolumn{1}{l}{ Oct } & Nov & \multicolumn{1}{l}{ Dec } \\
\hline 1986 & 183,24 & 90,14 & 150,17 & 217,09 & 98,50 & 57,80 & 77,27 & 47,27 & 55,53 & 102,12 & 173,30 & 122,17 \\
1987 & 123,18 & 90,14 & 150,17 & 109,92 & 98,50 & 57,80 & 31,79 & 14,82 & 9,25 & 40,12 & 100,58 & 122,17 \\
1988 & 183,24 & 202,24 & 150,17 & 109,92 & 98,50 & 95,08 & 31,79 & 14,82 & 9,25 & 40,12 & 173,30 & 122,17 \\
1989 & 183,24 & 202,24 & 90,34 & 154,58 & 143,12 & 95,08 & 77,27 & 47,27 & 55,53 & 40,12 & 100,58 & 122,17 \\
1990 & 76,62 & 202,24 & 218,46 & 154,58 & 98,50 & 57,80 & 31,79 & 14,82 & 55,53 & 102,12 & 100,58 & 122,17 \\
1991 & 76,62 & 130,83 & 150,17 & 154,58 & 62,12 & 57,80 & 31,79 & 14,82 & 18,35 & 40,12 & 100,58 & 172,01 \\
1992 & 76,62 & 202,24 & 218,46 & 217,09 & 98,50 & 95,08 & 77,27 & 47,27 & 55,53 & 102,12 & 173,30 & 172,01 \\
1993 & 123,18 & 202,24 & 218,46 & 217,09 & 98,50 & 57,80 & 31,79 & 14,82 & 55,53 & 102,12 & 100,58 & 172,01 \\
1994 & 123,18 & 202,24 & 218,46 & 217,09 & 98,50 & 57,80 & 31,79 & 14,82 & 18,35 & 40,12 & 100,58 & 122,17 \\
1995 & 76,62 & 90,14 & 150,17 & 154,58 & 62,12 & 57,80 & 77,27 & 47,27 & 18,35 & 40,12 & 100,58 & 78,11 \\
1996 & 123,18 & 90,14 & 150,17 & 154,58 & 62,12 & 57,80 & 31,79 & 14,82 & 9,25 & 102,12 & 173,30 & 172,01 \\
1997 & 123,18 & 90,14 & 150,17 & 154,58 & 98,50 & 57,80 & 31,79 & 47,27 & 18,35 & 40,12 & 100,58 & 122,17 \\
1998 & 183,24 & 202,24 & 218,46 & 217,09 & 98,50 & 57,80 & 77,27 & 47,27 & 55,53 & 102,12 & 173,30 & 78,11 \\
1999 & 123,18 & 202,24 & 150,17 & 109,92 & 98,50 & 57,80 & 31,79 & 14,82 & 9,25 & 40,12 & 100,58 & 122,17 \\
\hline
\end{tabular}




\begin{tabular}{rrrrrrrrrrrrr}
\hline 2000 & 123,18 & 90,14 & 150,17 & 154,58 & 143,12 & 95,08 & 31,79 & 14,82 & 9,25 & 40,12 & 100,58 & 78,11 \\
2001 & 183,24 & 90,14 & 150,17 & 154,58 & 98,50 & 95,08 & 77,27 & 47,27 & 55,53 & 102,12 & 173,30 & 78,11 \\
2002 & 183,24 & 202,24 & 150,17 & 217,09 & 62,12 & 57,80 & 31,79 & 14,82 & 9,25 & 40,12 & 100,58 & 122,17 \\
2003 & 183,24 & 130,83 & 90,34 & 154,58 & 98,50 & 57,80 & 31,79 & 14,82 & 18,35 & 40,12 & 173,30 & 122,17 \\
2004 & 123,18 & 90,14 & 150,17 & 109,92 & 98,50 & 57,80 & 31,79 & 14,82 & 18,35 & 40,12 & 100,58 & 122,17 \\
2005 & 183,24 & 90,14 & 218,46 & 217,09 & 62,12 & 57,80 & 31,79 & 14,82 & 9,25 & 40,12 & 100,58 & 122,17 \\
2006 & 76,62 & 90,14 & 90,34 & 154,58 & 98,50 & 57,80 & 31,79 & 14,82 & 18,35 & 40,12 & 100,58 & 122,17 \\
2007 & 76,62 & 202,24 & 218,46 & 154,58 & 98,50 & 57,80 & 31,79 & 14,82 & 18,35 & 40,12 & 173,30 & 172,01 \\
2008 & 123,18 & 130,83 & 150,17 & 217,09 & 98,50 & 57,80 & 31,79 & 14,82 & 9,25 & 40,12 & 100,58 & 172,01 \\
2009 & 76,62 & 130,83 & 150,17 & 154,58 & 143,12 & 95,08 & 77,27 & 14,82 & 9,25 & 40,12 & 100,58 & 122,17 \\
2010 & 183,24 & 202,24 & 218,46 & 217,09 & 143,12 & 95,08 & 77,27 & 47,27 & 55,53 & 102,12 & 173,30 & 172,01 \\
2011 & 76,62 & 130,83 & 150,17 & 154,58 & 98,50 & 95,08 & 31,79 & 14,82 & 9,25 & 40,12 & 100,58 & 122,17 \\
2012 & 76,62 & 130,83 & 90,34 & 154,58 & 62,12 & 57,80 & 31,79 & 14,82 & 18,35 & 40,12 & 100,58 & 172,01 \\
2013 & 183,24 & 202,24 & 218,46 & 154,58 & 98,50 & 95,08 & 77,27 & 47,27 & 55,53 & 102,12 & 100,58 & 122,17 \\
\hline
\end{tabular}

\section{KESIMPULAN}

Metode korelasi spasial hujan-debit (metode kontinu) dan metode diskrit Markov merupakan metode yang efektif digunakan dalam model prakiraan debit masa depan. Berdasarkan hasil simulasi diperoleh bahwa nilai korelasi prakiraan debit inflow Waduk Saguling dengan metode kontinu lebih besar dibandingkan dengan metode diskrit Markov. Korelasi prakiraan debit dan debit historis dengan metode kontinu sebesar 0,86 sedangkan dengan metode diskrit Markov sebesar 0,804. Simulasi pengelolaan Waduk Saguling secara optimal berkontribusi dalam penyusunan Pedoman Operasi dan Pemeliharaan (SOP) Waduk Saguling sehingga fungsi waduk dapat berlangsung sesuai dengan fungsi yang telah direncanakan sebelumnya.

\section{DAFTAR PUSTAKA}

Abatzoglou, JT., 2009, Classification of Regional Climate Variability in the State of California, Journal of Applied Meteorology and Climatology 48, 15271541.

Arwin, 2002, Tren Global Pembangunan Infrastruktur Sumber Daya Air yang berkelanjutan Dalam rangka Diskusi Pakar Perumusan Kebijakan Eco-Efficient Water Infrastructure Indonesia, Direktorat Pengairan dan Irigasi.
Arwin, 2009, Perubahan Iklim,Konversi Lahan Dan Ancaman Banjir Dan Kekeringan Di Kawasan Terbangun. Pidato Ilmiah Guru Besar, ITB Bandung.

Benabdesselam, Tamara and Amarchi, Hocine, 2013, Regional Approach for the Estimation of Extreme Daily Precipitation on North-East Area of Algeria, International Journal of Water Resources dan Environmental Engineering, Vol 5 (10), 573- 583

Null, Sarah E., Josué Medellín-Azuara, Alvar Escriva-Bou, Michelle Lent, Jay R. Lund (2014) : Optimizing the Dammed: Water Supply Losses and Fish Habitat Gains From Dam Removal in California. Journal of Environmental Management, 136, 121131

Read L., Kaveh Madani, Bahareh Inanloo, 2014, Optimality Versus Stability in Water Resource Allocation, Journal of Environmental Management 133, 343-354

$\mathrm{Xu}$, Xinyi, Lingling Bin, Chengzhong Pan, Aizhong Ding dan Desheng Chen (2014), Optimal Reoperation of Multi-Reservoirs for Integrated Watershed Management with Multiple Benefits, Water 2014, 6, 796812. College of Water Sciences. Beijing Normal University. 